\title{
GMR
}

\section{Genetic progress estimation strategy for upright common bean plants using recurrent selection}

\author{
L.A. Pereira ${ }^{1}$, A.F.B. Abreu ${ }^{2}$, I.C. Vieira Júnior ${ }^{1}$, L.P.M. Pires ${ }^{3}$ and \\ M.A.P. Ramalho ${ }^{1}$ \\ ${ }^{1}$ Departamento de Biologia, Universidade Federal de Lavras Federal, \\ Lavras, MG, Brasil \\ ${ }^{2}$ Embrapa Arroz e Feijão, Goiânia, GO, Brasil \\ ${ }^{3}$ Departamento de Agricultura, Universidade Federal de Lavras, \\ Lavras, MG, Brasil \\ Corresponding author: L.A. Pereira \\ E-mail: andrade.lais@gmail.com
}

Genet. Mol. Res. 16 (1): gmr16019494

Received October 27, 2016

Accepted December 19, 2016

Published March 22, 2017

DOI http://dx.doi.org/10.4238/gmr16019494

Copyright $(\underset{0}{ } 2017$ The Authors. This is an open-access article distributed under the terms of the Creative Commons Attribution ShareAlike (CC BY-SA) 4.0 License

\begin{abstract}
Common bean producers in Brazil tend to grow plants as upright as possible. Because the control of this trait involves a large number of genes, recurrent selection (RS) is the best approach for successful plant improvement. Because plant architecture (PA) is evaluated using scores and usually has high heritability, RS for PA is performed through visual selection in generation $\mathrm{S}_{0}$. The aim of the present study was to evaluate selection progress and investigate whether this progress varies with the number of selected progenies or the generation evaluated. In addition, the effect of RS for the upright (PA) trait on progeny grain yield (GY) was investigated. Data of progenies $\mathrm{S}_{0: 3}$ and $\mathrm{S}_{0: 4}$ of the fifth, eighth, and twelfth cycles were used. A combined analysis of variance was performed using the adjusted means of the 47 best progenies from each generation and cycle, using two control cultivars as reference. A joint analysis of the two generations
\end{abstract}

Genetics and Molecular Research 16 (1): gmr16019494 
used during the evaluation of progenies for the different cycles was also performed. The genetic progress (GP) was estimated by fitting a linear regression equation to the relationship between the adjusted mean of each cycle and the number of cycles. We found that RS was efficient and the estimated GP of the evaluated progenies was $4.5 \%$. Based on the GY heritability estimates, in more advanced generation selection for GY can be successfully performed on progenies. Thus, the selection already done for PA in $\mathrm{F}_{2}$ could be associated to the most productive progenies.

Key words: Phaseolus vulgaris; Upright plants; Grain yield; Selection progress; Recurrent selection

\section{INTRODUCTION}

Common bean cultivation in Brazil has undergone major changes during the last forty years, to meet the demands of farmers, traders, and consumers. During this period, bean production has changed from being based predominantly on family-based farms to also being performed by large agricultural companies on extensive irrigated areas.

Plant breeders of all species have focused on the plant architecture (PA) trait since the 1970s (Donald, 1968; Adams, 1973). Upright common bean plants have caught Brazilian breeders' attention since 1974. Initially, this trait represented efforts to decrease losses resulting from periods of intense rainfall coinciding with harvest. The more upright the plant, the less contact the pods have with moist soil, reducing crop losses and producing better quality grain. With the increased mechanization of crop production that began in the 1980s, the use of more upright plants provided additional advantages, including ease of movement for agricultural machinery for operations such as weed control, pesticide application, and mechanical harvesting, resulting in decreased harvest losses. In addition, the use of more upright plants improves air circulation, thus decreasing the severity of some pathogens, especially white mold (Miklas et al., 2006).

Because PA depends on the expression of several traits (Acquaah et al., 1991, Teixeira et al., 1999; Kelly, 2000; Soltani et al., 2016), its control involves a large number of genes (Basset, 2004). In these cases, recurrent selection (RS, i.e., selection followed by recombination of the best individuals or progenies during successive cycles of selection) is the best approach for successful plant improvement (Ramalho et al., 2005; Silva et al., 2010; Bernardo, 2014).

Any of the methods that are commonly used for obtaining segregating populations of autogamous plants can be used for RS. However, the method that results in the shortest selection cycle should be used whenever possible (Fouilloux and Bannerot, 1988). When the selected trait is expressed before flowering, phenotypic/mass selection is preferred. In this case, selection can be performed in $\mathrm{S}_{0}$, and the selected individuals can be recombined immediately. In the case of upright plants, it has been observed that the association with PA, as evaluated by scoring at flowering and at harvesting, is very high. RS for upright architecture can therefore be performed by mass selection.

The Federal University of Lavras (Universidade Federal de Lavras; UFLA), Brazil, began an RS program in 2001 with the goal of obtaining more upright plants with "carioca" type grain (beige with brown stripes). Selection was performed following the evaluation

Genetics and Molecular Research 16 (1): gmr16019494 
of $S_{0: 3}$ progenies for the first three cycles (Menezes Júnior et al., 2008). Starting at cycle III, phenotypic RS was performed in plants from the $\mathrm{S}_{0}$ generation, the upright plants were intercrossed to obtain an " $\mathrm{F}_{1}$ " generation. After that, the $\mathrm{F}_{2}=\mathrm{S}_{0}$ generation was obtained and the process was repeated. In this way, each cycle was completed after two seasons. Because three seasons can be performed per year in the study region, three RS cycles can be completed every two years. After this new strategy was adopted, $\mathrm{S}_{0: 1}$ progenies were obtained every three or four cycles. These progenies were evaluated for PA and grain yield (GY) in successive generations to obtain new lines. This procedure was adopted in cycles five (CV), eight (CVIII), and twelve (CXII).

Periodical evaluation of the selection progress throughout the RS program is essential. This is easily performed for allogamous plants because the populations are in equilibrium after each selection cycle. In autogamous plants, however, other strategies have been used, such as the evaluation of lines that are obtained after each selection cycle using control cultivars as a reference (Silva et al., 2010). Other studies that evaluated GY and other traits also used control cultivars and $\mathrm{S}_{0: 1}$ or $\mathrm{S}_{0: 2}$ progenies to evaluate the efficiency of RS (Ranalli, 1996; Amaro et al., 2007; Silva et al., 2007).

Although several methods have been used, the effect of the interaction with harvest/ year on the selection progress (based on the evaluation of progenies from more than one segregating generation) and the dependence of the RS progress on the number of progenies evaluated have not been tested. The aim of the present study was to evaluate the progress of phenotypic RS for upright bean plants between cycles CV and CXII using data of progenies $\mathrm{S}_{0: 3}$ and $\mathrm{S}_{0: 4}$. We also wanted to investigate the simulated effect of different progeny number on the estimates.

\section{MATERIAL AND METHODS}

The base population for the program of RS for upright plants was obtained from a diallel cross involving ten genitors, from which 42 populations were obtained and evaluated. From 11 selected populations, $190 \mathrm{~S}_{0: 1}$ progenies were obtained. Experiments were performed to evaluate these progenies and the best $60 \mathrm{~S}_{0: 2}$ progenies were selected. Ten $\mathrm{S}_{0: 3}$ progenies were chosen for recombination, originating from the cycle I (CI) population of RS. The process was repeated to obtain cycle II (CII) and cycle III (CIII) populations. Further details about the procedures and results up to CIII are reported in Cunha et al. (2005) and Menezes Júnior et al. (2008).

From CIII, phenotypic mass selection was adopted. The $\mathrm{S}_{0}$ plants were recombined based on PA scores, and $F_{1}$ seeds were multiplied and harvested in bulk to obtain the new $S_{0}$ population. This procedure was repeated until CXII. At CV, in addition to recombination to obtain next cycle, $\mathrm{S}_{0: 1}$ progenies were obtained. These progenies were evaluated in successive generations using replicated experiments until new lines were obtained. Two control cultivars were used as a reference in these evaluations: BRSMG Majestoso (which was chosen as the yield standard for "carioca" bean cultivars) and BRS Supremo (a black bean cultivar, which was chosen as the reference for upright PA). PA and GY were assessed in all evaluations. This procedure was repeated for CVIII and CXII. Further details about the use of RS in these cycles are reported in Pires et al. (2014).

The present study focused on evaluating the $\mathrm{S}_{0: 3}$ and $\mathrm{S}_{0: 4}$ progenies of CV, CVIII, and CXII. Details of the experiments are presented in Table 1.

Genetics and Molecular Research 16 (1): gmr16019494 
Table 1. Evaluation of the $\mathrm{S}_{0: 3}$ and $\mathrm{S}_{0: 4}$ progenies for CV, CVIII, and CXII of the RS program selecting for upright plants.

\begin{tabular}{|c|c|c|c|}
\hline \multirow{2}{*}{\multicolumn{2}{|c|}{ Cycle }} & \multicolumn{2}{|c|}{ Generation } \\
\hline & & $\mathrm{S}_{0: 3}$ & $\mathrm{~S}_{0: 4}$ \\
\hline \multirow[t]{4}{*}{$\mathrm{CV}$} & Number of progenies & 47 & 47 \\
\hline & Number of replicates & 3 & 3 \\
\hline & Experimental design & $7 \times 7$ lattice & $7 \times 7$ lattice \\
\hline & Sowing season & July 2009 & November 2009 \\
\hline \multirow[t]{4}{*}{ CVIII } & Number of progenies & 98 & 47 \\
\hline & Number of replicates & 3 & 3 \\
\hline & Experimental design & $10 \times 10$ lattice & $7 \times 7$ lattice \\
\hline & \begin{tabular}{|l|} 
Sowing season \\
\end{tabular} & November 2011 & February 2012 \\
\hline \multirow[t]{4}{*}{ CXII } & Number of progenies & 62 & 62 \\
\hline & Number of replicates & 3 & 3 \\
\hline & Experimental design & $8 \times 8$ lattice & $8 \times 8$ lattice \\
\hline & Sowing season & November 2013 & March 2014 \\
\hline
\end{tabular}

The experiments for each cycle were conducted at Lavras, which is located at 919 $\mathrm{m}$ altitude, $21^{\circ} 14^{\prime} \mathrm{S}$ latitude and $45^{\circ} 59^{\prime} \mathrm{W}$ longitude. PA and GY were evaluated. PA scores were attributed using a scoring scale from 1 to 9 , where 1 represents non-upright plants and 9 represents fully upright plants.

First, an analysis of variance was performed for $\mathrm{S}_{0: 3}$ and the subsequent $\mathrm{S}_{0: 4}$ progenies for each studied cycle. A combined analysis of variance was performed using the adjusted means of the 47 common progenies for each generation and cycle using the two control cultivars. A joint analysis using the means of the two progeny generations that were evaluated for the different cycles, which were obtained from the combined analysis, was also performed (Petersen, 1994).

From the results of the analyses of variance, an accuracy estimate $\left(r_{g g}\right.$, was obtained using the following expression:

$$
r_{g g^{\prime}}=\sqrt{1-(1 / F)}
$$

in which F: progenies' mean square/residual mean square.

For the estimate of broad sense heritability $\left(h^{2}\right)$ of the progenies from the analysis of variance, estimates of the mean squares of progenies (MSP), and the mean square error (MSE) were used:

$$
h^{2}=\frac{M S P-M S E}{M S P}
$$

The errors associated with the estimate of $h^{2}$ were estimated using the following expressions from Knapp et al. (1985):

$$
L L=\left\{1-\left[\left(\frac{M S P}{M S E}\right) F_{1-\alpha / 2}\left(d \cdot f_{\cdot E R R O R} ; d \cdot f_{P_{\text {Progenies }}}\right)\right]^{-1}\right\} \text { and (Equation 3) }
$$

Genetics and Molecular Research 16 (1): gmr16019494 


$$
U L=\left\{1-\left[\left(\frac{M S P}{M S E}\right) F_{\alpha / 2}\left(d \cdot f_{E_{\text {ERROR }}} ; d \cdot f_{\cdot \text { Progenies }}\right)\right]^{-1}\right\}
$$

(Equation 4)

in which LL is the lower limit, UL is the upper limit, and F are table values from an F distribution with d.f. (degrees of freedom) progenies and d.f. error. The $\alpha$ was set to 0.05 .

The adjusted means that were obtained from the joint analysis were used to estimate the genetic progress (GP). Initially, the mean of the 47 progenies from CV, CVIII, and CXII for each generation were considered; subsequently, the mean of the two generations was considered. To estimate GP, a linear regression equation was fitted to the relationship between the mean of each cycle (dependent variable; $Y$ ) and the number of cycles (independent variable; X). The slope (b) of this regression corresponds to the RS progress per cycle. GP was calculated as b divided by the mean of the fifth cycle, considered as the original cycle, multiplied by 100, and expressed as a percentage per selection cycle. GP was calculated for the PA scores and GY data.

To investigate a possible effect of the number of progenies evaluated, $b$ was estimated using the means of the five ( $10 \%$ selection intensity) or ten ( $20 \%$ selection intensity) best progenies for each situation, out of the 47 evaluated with the combined analysis.

The genetic correlation between the PA and GY means of $\mathrm{S}_{0: 3}$ and $\mathrm{S}_{0: 4}$, for each cycle, was estimated applying the procedure presented by Falconer and Mackay (1996).

\section{RESULTS}

Variations in overall mean GY and PA scores were observed between the progenies of the $\mathrm{S}_{0: 3}$ and $\mathrm{S}_{0: 4}$ generations for the different RS cycles (Table 2). For all cycles, mean GY was higher for progenies of the $\mathrm{S}_{0: 4}$ generation than for those of the $\mathrm{S}_{0: 3}$ generation. Mean PA scores were similar among the different generations within the same cycle. The accuracy values ranged from 0.39 to 0.91 for PA and from 0.70 to 0.93 for GY.

Table 2. Mean plant architecture scores (scale 1 to 9 ) and grain yield ( $\mathrm{kg} / \mathrm{ha}$ ) per cycle and generation. The accuracy values are given in brackets.

\begin{tabular}{l|c|c|c|c|c|c}
\hline \multirow{2}{*}{ Cycle } & \multicolumn{3}{|c|}{ Plant architecture score } & \multicolumn{3}{c}{ Grain yield } \\
\cline { 2 - 7 } & $\mathrm{S}_{0: 3}$ & $\mathrm{~S}_{0: 4}$ & Mean & $\mathrm{S}_{0: 3}$ & $\mathrm{~S}_{0: 4}$ & Mean \\
\hline CV & $5.7(0.74)$ & $5.7(0.75)$ & 5.7 & $1460(0.70)$ & $2339(0.86)$ & 1901 \\
\hline CVIII & $5.9(0.39)$ & $5.8(0.78)$ & 5.8 & $1786(0.93)$ & $2813(0.78)$ & 2304 \\
\hline CXII & $7.2(0.91)$ & $7.7(0.85)$ & 7.5 & $1684(0.73)$ & $2728(0.71)$ & 2206 \\
\hline
\end{tabular}

If RS is efficient, the PA score should increase with successive selection cycles. This was observed especially for cycles CVIII and CXII (Table 2). However, the same tendency was not observed for GY.

In the present study, some estimated PA $h^{2}$ values were low (Table 3). For GY, $h^{2}$ ranged from 0.49 to 0.87 . The observed $h^{2}$ values varied among cycles and the generation evaluated. However, with the exception of $\mathrm{S}_{0: 3}$ CVIII for PA, all the estimates of $h^{2}$ were significantly different from zero, as the lower confidence interval limits demonstrate. For GY the all the estimates were different from zero, and their values were similar to the PA values.

Genetics and Molecular Research 16 (1): gmr16019494 
Table 3. Estimated heritability and confidence intervals for plant architecture scores and grain yield $(\mathrm{kg} / \mathrm{ha})$ for the $\mathrm{S}_{0: 3}$ and $\mathrm{S}_{0: 4}$ progenies.

\begin{tabular}{l|c|c|c|c}
\hline \multirow{2}{*}{ Cycle } & \multicolumn{2}{|c|}{ Plant architecture score } & \multicolumn{2}{c}{ Grain yield } \\
\cline { 2 - 5 } & $\mathrm{S}_{0: 3}$ & $\mathrm{~S}_{0: 4}$ & $\mathrm{~S}_{0: 3}$ & $\mathrm{~S}_{0: 4}$ \\
\hline CV & $0.54(0.26-0.74)$ & $0.56(0.28-0.74)$ & $0.49(0.16-0.70)$ & $0.74(0.56-0.84)$ \\
\hline CVIII & $0.15(-0.19-0.41)$ & $0.61(0.36-0.77)$ & $0.87(0.82-0.91)$ & $0.61(0.37-0.77)$ \\
\hline CXII & $0.83(0.48-0.79)$ & $0.73(0.59-0.83)$ & $0.54(0.29-0.7)$ & $0.51(0.25-0.69)$ \\
\hline
\end{tabular}

The regressions between cycle number and PA or GY were all positive, albeit not significant in most cases (Tables 4 and 5). The coefficients of determination $\left(\mathrm{R}^{2}\right)$ for PA were always high, whereas they tended to be low for GY. When the mean of the $\mathrm{S}_{0: 3}$ and $\mathrm{S}_{0: 4}$ progenies was considered, SG was greater than $4.4 \%$, and the $\mathrm{R}^{2}$ was always high. This indicates a good fit of the linear equation to the data. The behavior of the overall mean architecture score for the different cycles, as discussed above, explains the good fit obtained. It is important to remember that one of the aims of the present study was to investigate whether the GP estimation varied depending on the number of progenies used for the estimate.

Table 4. Linear regression coefficients (b) and their associated P-values (P), selection gain (SG, \%), and coefficient of determination $\left(\mathrm{R}^{2}\right)$ for plant architecture (scored from 1 to 9 ) for the $\mathrm{S}_{0: 3}$ and $\mathrm{S}_{0: 4}$ progenies resulting from RS for plant architecture, considering different selection intensities (Progeny No.).

\begin{tabular}{|c|c|c|c|c|c|c|c|c|c|c|c|c|}
\hline \multirow[t]{2}{*}{ Progeny No. } & \multicolumn{4}{|c|}{$\mathrm{S}_{0: 3}$} & \multicolumn{4}{|c|}{$\mathrm{S}_{0: 4}$} & \multicolumn{4}{|c|}{ Mean } \\
\hline & $\mathrm{b}$ & $\mathrm{P}$ & $\mathrm{R}^{2}$ & SG & $\mathrm{b}$ & $\mathrm{P}$ & $\mathrm{R}^{2}$ & SG & $\mathrm{b}$ & $\mathrm{P}$ & $\mathrm{R}^{2}$ & SG \\
\hline 47 & 0.22 & 0.22 & 0.88 & 3.80 & 0.29 & 0.27 & 0.83 & 5.13 & 0.26 & 0.25 & 0.85 & 4.46 \\
\hline 10 & 0.23 & 0.06 & 0.99 & 3.42 & 0.30 & 0.16 & 0.94 & 4.49 & 0.28 & 0.15 & 0.94 & 4.41 \\
\hline 5 & 0.23 & 0.02 & 1.00 & 3.45 & 0.28 & 0.12 & 0.96 & 3.99 & 0.28 & 0.05 & 0.99 & 4.22 \\
\hline
\end{tabular}

Table 5. Linear regression coefficients (b) and their associated $\mathrm{P}$-values $(\mathrm{P})$, selection gain (SG, \%), and coefficient of determination $\left(\mathrm{R}^{2}\right)$ for grain yield $\left(\mathrm{kg} / \mathrm{ha}\right.$ ) for the $\mathrm{S}_{0: 3}$ and $\mathrm{S}_{0: 4}$ progenies resulting from RS for plant architecture, considering different selection intensities (Progeny No.).

\begin{tabular}{|c|c|c|c|c|c|c|c|c|c|c|c|c|}
\hline \multirow[t]{2}{*}{ Progeny No. } & \multicolumn{4}{|c|}{$\mathrm{S}_{0: 3}$} & \multicolumn{4}{|c|}{$\mathrm{S}_{0: 4}$} & \multicolumn{4}{|c|}{ Mean } \\
\hline & $\mathrm{b}$ & $\mathrm{P}$ & $\mathrm{R}^{2}$ & SG & $\mathrm{b}$ & $\mathrm{P}$ & $\mathrm{R}^{2}$ & SG & $\mathrm{b}$ & $\mathrm{P}$ & $\mathrm{R}^{2}$ & SG \\
\hline 47 & 28.81 & 0.58 & 0.37 & 1.97 & 51.47 & 0.49 & 0.51 & 2.20 & 39.68 & 0.54 & 0.44 & 2.09 \\
\hline 10 & 18.66 & 0.83 & 0.11 & 0.97 & 70.20 & 0.37 & 0.69 & 2.53 & 41.63 & 0.56 & 0.40 & 1.83 \\
\hline 5 & 25.35 & 0.75 & 0.15 & 1.26 & 68.05 & 0.39 & 0.68 & 2.34 & 45.52 & 0.59 & 0.36 & 1.97 \\
\hline
\end{tabular}

Another aim of the present study was to investigate whether the GP estimation depended on the progeny $\mathrm{x}$ generation (sowing season) interaction. The GP of selection for PA score estimated for $\mathrm{S}_{0: 3}$ and $\mathrm{S}_{0: 4}$, as well as for the overall mean of the two generations were very similar, as mentioned above (Table 4). The genetic correlation between PA and GY varied across cycles, but all the values were low, suggesting low interaction between progeny $\mathrm{x}$ generation. The genetic correlations for cycles V, VII and XII were 0.23, 0.58 and 0.10, respectively.

\section{DISCUSSION}

It is important to remember that under field conditions, it is easy to identify upright plants to intercross and generate the next population. With the exception of $\mathrm{S}_{0: 3}$ CVIII, the $h^{2}$

Genetics and Molecular Research 16 (1): gmr16019494 
estimates were all different from zero and high, suggesting the presence of variability to be explored for successful selection (Table 3). Even though the $h^{2}$ estimated here was at progeny level and the selection was made at the plant/individual level, the estimates still suggest that the environmental effect might not be important to PA expression.

To our knowledge, there have been no studies conducting PA $h^{2}$ estimates based on evaluations of individual plants. However, when evaluating progenies, as done in this work, estimates found in other studies were similar to ours (Cunha et al., 2005; Menezes Júnior et al., 2008). Importantly, the PA score has a relatively small range of variation (1 to 9), and its $h^{2}$ estimates are therefore difficult to compare to those of other traits, such as GY.

Because the occurrence of dominance is less important than additive effects in autogamous plants (Ramalho et al., 2012; Bernardo, 2014), the progeny mean is not expected to vary between successive generations of the same RS cycle. This pattern was observed for PA score. For GY, the overall mean for the $\mathrm{S}_{0: 4}$ generation was always higher than that for the $\mathrm{S}_{0: 3}$ generation (Table 2). Considering the aforementioned findings, this can only be explained by environmental effects because, even if allele dominance occurred, this would result in lower means for $\mathrm{S}_{0: 4}$ than for $\mathrm{S}_{0: 3}$ rather than the reverse. In addition, the frequency of heterozygous loci for the $\mathrm{S}_{0: 3}$ and $\mathrm{S}_{0: 4}$ generations has been found to be relatively small, and the dominance effect should therefore not be pronounced (Bos and Caligari, 1995; Bernardo, 2014).

Based on the overall mean, GP for PA was $4.5 \%$. The values found in previous studies have been very variable depending on population and selection method. The most appropriate in this case is to compare our results to those found in studies that also used scores. For studies on common beans, especially angular leaf spot resistance, the estimates obtained in the present study were similar to those found in the literature (Amaro et al., 2007; Arantes et al., 2010; Rezende et al., 2014).

GP estimates for some bean plant traits, which were obtained using different evaluation methods, have previously been reported. Comparisons are not easily made due to variation in the RS method used, the number of cycles, and the precise trait evaluated. For example, for GY, Beaver and Kelly (1994) estimated a GP of 30\% after three cycles, whereas Ramalho et al. (2005) estimated a GP of 5.7\%. Regarding traits evaluated using scores, similarly to PA, the GP of selection for resistance to angular leaf spot was reportedly $6.3 \%$ after six cycles (Amaro et al., 2007) or almost null (Arantes et al., 2010) for the same population.

There was no large difference in GP when analyzing different number of progenies. This effect has never been explored before. In previous results, when evaluating GP by evaluating progenies, different progeny numbers have been used (Ranalli, 1996).

Another aim in this research was to verify the progeny $\mathrm{x}$ environment interaction effect on the GP estimate. To do this, two generations were used, $\mathrm{S}_{0: 3}$ and $\mathrm{S}_{0: 4}$. For PA, all the estimates were very similar, suggesting that, in this case, this interaction did not affect GP. We found no previous work examining this aspect.

We also investigate the effects of RS for PA on GY. When selection for PA is performed, the plant breeder has no indication of the potential productivity of the plant that is being recombined. This is especially true because the hybridization experiments begin immediately after the first flowers appear, and it cannot be predicted whether the plant will produce many more flowers or whether the flower setting will be high. As previously discussed, the mean estimates for GY for successive cycles showed no consistent tendency suggesting an increase with RS progress. This was supported by the lower GP observed for GY than for the PA score (Table 5). It can thus be inferred that recurrent selection for PA as 
done in this work, does not affect GY. This is also supported by the low genetic correlation values. It is possible that PA and GY might be genetically independent traits, as suggested previously by Collicchio et al. (1997).

A suggested strategy is to visually select for $\mathrm{PA}$, in the $\mathrm{S}_{0}$ generation, obtaining progenies in later generations, and then select for GY. If this strategy is adopted, it might be possible to successfully improve both traits. Amaro et al. (2007) performed RS for resistance to angular leaf spot and reported a selection gain of $6.4 \%$ per cycle. This increased resistance to the pathogen resulted in a GP of $8.9 \%$ for GY after five cycles of RS. Arantes et al. (2010) also performed RS for resistance to angular leaf spot and estimated a selection gain of $2.3 \%$ for GY. This discrepancy occurs because pathogen severity is correlated with yield, whereas PA does not appear to be correlated with GY, as discussed above. In more advanced generations, selection for GY can be successfully performed using progenies based on GY $h^{2}$ estimates (Table 3). Thus, the selection already done for PA in $\mathrm{F}_{2}$ could be associated with the most productive progenies.

To conclude, different number of progenies did not affect the GP estimates, the same was true for the progeny $\mathrm{x}$ environment interaction. When selecting for PA there was no indirect response in GY and the mean GP by selection cycle for PA was $4.5 \%$.

\section{Conflicts of interest}

The authors declare no conflict of interest.

\section{ACKNOWLEDGMENTS}

We are grateful to Coordenação de Aperfeiçoamento de Pessoal de Nível Superior (CAPES), and Conselho Nacional de Desenvolvimento Científico e Tecnológico (CNPq) for granting the scholarship and to Fundação de Amparo à Pesquisa do Estado de Minas Gerais (FAPEMIG) for financial support to realize this research project.

\section{REFERENCES}

Acquaah G, Adams MW and Kelly JD (1991). Identification of effective indicators of erect plant architecture in dry bean. Crop Sci. 31: 261-264. http://dx.doi.org/10.2135/cropsci1991.0011183X003100020004x

Adams MW (1973). Plant architecture and physiological efficiency. In: Potential of field beans and other food legumes in Latin America. CIAT, Cali, 226-278.

Amaro GB, Abreu AFB, Ramalho MAP and Silva FB (2007). Phenotypic recurrent selection in the common bean (Phaseolus vulgaris L.) with carioca-type grains for resistance to the fungi Phaeoisairopsis griseola. Genet. Mol. Biol. 30: 584-588. http://dx.doi.org/10.1590/S1415-47572007000400014

Arantes LO, Abreu AFB and Ramalho MAP (2010). Eight cycles of recurrent selection for resistance to angular leaf spot in common bean. Crop Breed. Appl. Biotechnol. 10: 232-237.

Basset MJ (2004). List of genes - Phaseolus vulgaris L. Annu. Rep. Bean Improv. Coop. 47: 1-24.

Beaver JS and Kelly JD (1994). Comparison of selection methods for dry bean populations derived from crosses between gene pools. Crop Sci. 34: 34-37. http://dx.doi.org/10.2135/cropsci1994.0011183X003400010005x

Bernardo R (2014). Essentials of plant breeding. Stemma Press, Woodbury.

Bos I and Caligari P (1995). Selection methods in plant breeding. Chapman and Hall, London.

Collicchio E, Ramalho MAP and Abreu AFB (1997). Associação entre o porte da planta do feijoeiro e o tamanho dos grãos. Pesqui. Agropecu. Bras. 32: 297-304.

Cunha WG, Ramalho MAP and Abreu AFB (2005). Selection aiming at upright growth habit of common bean with carioca type grains. Crop Breed. Appl. Biotechnol. 5: 379-386. http://dx.doi.org/10.12702/1984-7033.v05n04a02

Genetics and Molecular Research 16 (1): gmr16019494 
Donald CM (1968). The breeding of crop ideotypes. Euphytica 17: 385-403. http://dx.doi.org/10.1007/BF00056241

Falconer DS and Mackay TFC (1996). Introduction to quantitative genetics. 4th edn. London, Longman.

Fouilloux G and Bannerot H (1988). Selection methods in the common bean (Phaseolus vulgaris L.). In: Genetic resources of Phaseolus beans (Gepts P ed.). Klüwer Academic Publishers, Dordrecht, 503-541.

Kelly JD (2000). Remaking bean architecture for efficient production. Adv. Agron. 71: 109-143. http://dx.doi.org/10.1016/ $\underline{\text { S0065-2113(01)71013-9 }}$

Knapp SJ, Stroup WW and Ross WM (1985). Exact confidence intervals for heritability on a progeny mean basis. Crop Sci. 25: 192-194. http://dx.doi.org/10.2135/cropsci1985.0011183X002500010046x

Menezes Júnior JAN, Ramalho MAP and Abreu AFB (2008). Seleção recorrente para três caracteres do feijoeiro. Bragantia 67: 833-838. http://dx.doi.org/10.1590/S0006-87052008000400004

Miklas PN, Kelly JD, Beebe SE and Blair MW (2006). Common bean breeding for resistance against biotic and abiotic stress: From classical to MAS selection. Euphytica 147: 105-131. http://dx.doi.org/10.1007/s10681-006-4600-5

Petersen RG (1994). Agricultural field experiments. Design and analysis. Marcel Dekker, Inc., New York.

Pires LPM, Ramalho MAP, Abreu AFB and Ferreira MC (2014). Recurrent mass selection for upright plant architecture in common bean. Sci. Agric. 71: 240-243. http://dx.doi.org/10.1590/S0103-90162014000300009

Ramalho MAP, Abreu AFB and dos Santos JB (2005). Genetic progress after four cycles of recurrent selection for yield and grain traits in common bean. Euphytica 144: 23-29. http://dx.doi.org/10.1007/s10681-005-5694-x

Ramalho MAP, Abreu AFB, dos Santos JB and Nunes JAR (2012). Aplicações da genética quantitativa no melhoramento de plantas autógamas. UFLA, Lavras.

Ranalli P (1996). Phenotypic recurrent selection in common bean (Phaseolus vulgaris L.) based on performance of S2 progenies. Euphytica 87: 127-132. http://dx.doi.org/10.1007/BF00021885

Rezende BA, Abreu AFB, Ramalho MAP and Souza EA (2014). Severity evaluation methods in common bean recurrent selection program for resistance to angular leaf spot. J. Phytopathol. 162: 643-649. http://dx.doi.org/10.1111/ iph. 12238

Silva FB, Ramalho MAP and Abreu AFB (2007). Seleção recorrente fenotípica para florescimento precoce de feijoeiro 'Carioca'. Pesqui. Agropecu. Bras. 42: 1437-1442. http://dx.doi.org/10.1590/S0100-204X2007001000010

Silva GS, Ramalho MAP, Abreu AFB and Nunes JAR (2010). Estimation of genetic progress after eight cycles of recurrent selection for common bean grain yield. Crop Breed. Appl. Biotechnol. 10: 351-356. http://dx.doi.org/10.1590/S1984$\underline{70332010000400010}$

Soltani A, Bello MH, Mndolwa E, Schroder S, et al. (2016). Targeted analysis of dry bean growth habit: Interrelationship among architectural, phenological and yield components. Crop Sci. 56: http://dx.doi.org/10.2135/cropsci2016.02.0119.

Teixeira FF, Ramalho MAP and Abreu AFB (1999). Genetic control of plant architecture in the common bean (Phaseolus vulgaris). Genet. Mol. Biol. 22: 577-582. http://dx.doi.org/10.1590/S1415-47571999000400019 